\title{
Valuing start-ups - selected approaches and their modification based on external factors
}

\author{
Martina Skalicka Dusatkova ${ }^{1}$, Marek Zinecker ${ }^{1}$ \\ 1 Faculty of Business and Management, Brno University of Technology, Kolejni 2906/4, 61200 Brno, Czech Republic \\ Corresponding author: Marek Zinecker (zinecker@fbm.vutbr.cz)
}

Received 26 December 2015

Accepted 31 May 2016

Published 10 November 2016

Academic editor:

Živile Tunčikiené

\section{Keywords}

venture capital

business angels

start-ups

valuation

model

beta coefficient

external determinants

macroeconomic determinants

\section{JEL Classification}

\begin{abstract}
The recent methods of start-up valuation seek to compensate for the lack of data necessary for a standard company valuation with additional information on the person of the entrepreneur and business project. None of the existing approaches, however, takes into consideration information about the environment in which the venture capitalists conduct their investments. Therefore, the aim of this paper is to develop an approach considering factors of the investee companies' environment. Such a modification will allow a more accurate estimate of the value of the projects investigated. The nature of this study is explorative. It relies on secondary data that was collected using interviews and semi-structured questionnaires in previous empirical studies. During the course of the modelling process, information on the quality of the investee companies' environment expressed is incorporated into the established start-up project valuations. Our original proposal consists of the modification of the $\beta$ coefficient calculation for a given type of projects. An essential part of this modification is also a proposal for the extension of the project scoring characteristics to include expert estimates and, in the case of regression analysis, the inclusion of explanatory variables expressing the suitability of the environment for venture capital investments.
\end{abstract}

G11, G23, G24

\section{Introduction}

The use of conventional valuation methods for business projects at an early stage of development (start-ups), which are often the target of venture capital and business angel activities, is rife with difficulties; at the same time, however, valuation is of utmost importance if a start-up is looking to raise money for its further development. Valuation methods are usually divided into three basic groups, i.e. valuation methods that rely on cash flows, comparable transactions, and analysis of assets (Kumar 2015). The difficulty of using these approaches in the valuation of start-ups lies mainly in the fact that start-ups can provide only very little information about their history (Miloud et al. 2012). This may be due to a lack of accounting data (short history, i.e. the company has neither profits nor revenues), the lack of market data (there are no comparable companies or no direct competitors) or the fact that most of the company's assets are intangible.
The existing methods of start-up valuation seek to compensate for the lack of information necessary for a standard company valuation with additional information on the person of the entrepreneur and business project. None of the existing approaches, however, takes into consideration information about the environment in which the venture capitalists are to make their investments, i.e. external factors influencing entrepreneurial success are not reflected in these models.

The model, proposed in this article, presents a modification of the existing valuation models of start-ups by considering factors of the investee companies' environment. Such a modification will allow a more accurate estimate of the value of the projects investigated. The novelty of this study is to focus on the analysis of external factors that influence the valuation of investee companies in the start-up stage. No previous paper has, to our knowledge, dealt with the issue of appropriate methodologies reflecting these factors. 


\section{Theoretical background}

New start-up firms face typically a lack of external financing. A large number of academic studies examining investment criteria and projects' valuation approaches emerged in the last two decades.

Nofsinger and Wang (2011) studied the determinants of the initial start-up financing in 27 countries and conclude that "institutional investors rely on the experience of entrepreneurs in managing start-ups and the quality of investor protection to reduce moral hazard". On the other hand, when evaluating start-up projects, the informal investors are rather "attracted to the type of products in the new firm" and "are likely to have a social relationship with the entrepreneur". Therefore, the entrepreneurial experience is perceived as less important. Carpentier and Suret (2015) investigated angel group members' decision-making from project submission to the final decision in Canada. The survey results suggest that inexperienced entrepreneurs are rejected for "market and product reasons" and that the "decision-making by the angel group members differs from that generally described for independent angels". Mitteness et al. (2012) also explored the weight of different investment criteria from the viewpoint of business angels and reflected the impact of industry experience on evaluations of projects. Authors conclude that "the entrepreneur matters most" within the decision making process. On the other hand, the opportunity matters when angels evaluate whether "a deal matches their own investment goals as the deal progresses through the funding process". Capizzi (2015) investigated the expost performance of business angels' investments in the Italian informal venture capital market. One of the main outcomes of the study based on an econometric analysis is that the relationship between experience and IRR of projects is U-shaped and significant. Festel et al. (2013) introduced the founding angels' concept as an emerging subtype of the angel investment model. Based on 16 case studies in Germany and Switzerland the authors provide empirical evidence to evaluate the potential of this investment model. Concerning the role the funding angels play Festel et al. (2013) point out rather their role of founders and then that of investors because of their "early engagement in the venture". The founding angels obviously complement venture capital infrastructure as they "normally support the start-up's efforts to raise funding".

Using the approach generally taken in finance theory, the value of investments is seen in the present value of its future cash flows (e.g. Brealey et al. 2007). When valuing start-ups, for which only few clues (information) are available, there is a relatively high risk of a considerable scatter of results (Miloud et al. 2012). The problem of a scarcity of relevant information for the valuation of startups, such as the lack of historical data, uncertainty about the factors influencing their future, unclear future cash flows, etc., is mentioned by many authors (e.g. Peemöller et al. 2001), who also point out the need for a method that will help both the entrepreneurs and the investors (ven- ture capitalists) reach a compromise during negotiations on the price of their funding.

Current studies offer several approaches to address the issue of information shortage when common start-up valuation methods are applied. Some authors propose the modification of current methods. The approach proposed by Festel et al. (2013) focuses on the beta coefficient of start-ups. Its value is projected into the cost of equity, i.e. the rate used when expected future cash flows are discounted. In this case, the authors drew on previous studies that looked into the criteria used by venture capitalists when making investment decisions. According to them, investors focus mainly on the entrepreneur's personality traits such as enthusiasm, credibility and experience, though also on potential sales (Van Osnabrugge and Robinson 2000). According to Sudek (2006), the management team and exit options are also important. Mason and Stark (2004) emphasize financial performance and verifiable business data (market share, sales, etc.). They also take into consideration the fact that the final cost of financing will depend not only on the status/position of an individual start-up, but also on market conditions (Gompers and Lerner 2000). Festel et al. (2013) drew closely on the research of Maxwell et al. (2011) who, categorized areas that business angels are interested in when valuating business proposals. When determining the cost of capital, they use the CAPM according to the following equation:

$$
E\left(R_{i}\right)=R_{f}+\beta_{i}\left[E\left(R_{m}\right)-R_{f}\right],
$$

where $E\left(R_{i}\right)$ is the expected rate of return on the asset, $E\left(R_{m}\right)$ is the risk-free interest rate, $\left[E\left(R_{m}\right)-R_{f}\right]$ is the expected return of the market, is the expected market risk premium and $\beta$ is the sensitivity of returns on asset $i$ to the expected excess market returns. The $\beta_{i}$ coefficient is calculated according to the following formula:

$$
\beta_{i}=\operatorname{Cov}\left(R_{i}, R_{m}\right) /\left(\sigma^{2}\left(R_{m}\right)\right),
$$

where $\operatorname{Cov}\left(R_{i}, R_{m}\right)$ is the covariance between the return on asset $i$ and the return of the market, and $\sigma^{2}\left(R_{m}\right)$ is the market yield spread. On the basis of research already conducted into investors' valuation criteria (Maxwell et al. 2011), the authors propose modifying the $\beta$ coefficient according to twenty criteria in five areas: 1) technology, 2) product, 3 ) the readiness and sophistication of the business plan, and 4) organization and finance. The evaluation of individual criteria takes place on a five-point scale. If the assessed category is satisfactory with respect to the project phase, the $\beta$ value remains unchanged. If the results are below average, its rating is 0.5 and 1 point (the further below the average, the higher the value); in the case of above-average valuation the values are -0.5 and -1 point (the better the valuation, the higher the absolute value). The points obtained for each criterion represent the amount of change to the $\beta$ coefficient value on the basis of that criterion evaluation. The overall change 
in the $\beta$ coefficient for the project valuated is the sum of points from the results of the individual criteria.

This approach reflects the qualitative characteristics such as e.g. the entrepreneur or management team in evaluation of project risks, expected returns, and thus the overall project valuation. The authors estimate what project characteristics are considered as risks and vice versa, and then make adjustments to the $\beta$ coefficient.

A similar approach has been proposed by Stankevičienè and Žinytė (2011). These authors consider the conventional valuation methods, such as discounted cash flows, multipliers or asset analysis, to be inadequate. They refer to research among venture capital investors who admit that start-up valuation is often a mere guessing game (Ge et al. 2005). Nevertheless, they again draw on previous research works which suggest that venture capital investors valued start-ups higher if they are in a sector with a differentiated product, if the entrepreneur has had previous experience with doing business and corporate management, if there are more people (co-owners) involved into the business plan, and if the enterprise has external partners (Ge et al. 2005). The study by Sanders and Boivie (2004) emphasizes the fact that venture capital and business angel investors are not interested only in quantitative criteria but also in qualitative criteria when valuating start-up companies. They propose a multi-criteria approach to start-up valuation, and use 22 criteria in six areas, namely 1) the personality of the entrepreneur, 2) external relations, 3) market opportunities, 4) the investment period, 5) financing, and 6) company profile.

The weights of individual criteria in the relevant areas are determined on the basis of an expert estimate. Criteria are rated on a five-point scale ( 1 - the weakest rating, 3 average criterion value, 5 - the highest rating). Start-up valuation is then expressed as the sum of the weighted ratings of the individual criteria.

Similarly to the previous approach, this is an attempt to take into account the qualitative characteristics of the evaluated business plans (such as the entrepreneur's personality, management team, etc.). Unlike the previous assessment, however, the result it offers is only a score which can serve for an initial monitoring of acceptable projects and a multi-stage selection (Maxwell et al. 2011).

The question of start-up valuation is also examined in the empirical work by Miloud et al. (2012). The authors point out that the existence of too many assumptions in a valuation by conventional methods often leads to a very wide scatter of results. They apply statistical methods (OLS, GLS) to data on transactions and their characteristics to estimate the direction and the sensitivity of the valuation factors. They draw attention to previous research which demonstrates that investors base their decisions on a number of criteria. In agreement with Silva (2004), they underscore the fact that venture capital investors will focus primarily on the entrepreneur himself, the business model, sustainable advantage and growth potential. Cash flow projections do not play a crucial role. The authors therefore conclude that if the project cannot be assessed by its outputs (generated free cash flow), it must be evaluated by the inputs available to it (which will influence its future outputs) such as the personal traits of the entrepreneur, the attractiveness of the sector, etc. From their perspective, the relevant factors in start-up valuation are the sector structure, resources and external relations.

Within the industry sector structure, they consider product differentiation (Porter 1980) and market growth important. In agreement with Timmons (1992), the resources they deem important include the personality of the entrepreneur, and especially a) his technical expertise in the industry and knowledge of the market (Siegel et al. 1993); b) experience in top management (Gimeno et al. 1997); and c) experience in entrepreneurial projects (Larson and Starr 1993). Important internal resources also include the management team, its completeness and heterogeneity (Franke et al. 2008), and whether it is a project of just one person or a team effort (Franke et al. 2008).

External relations play an important role in finding new opportunities, raising funds (at lower prices than on the open market) and gaining legitimacy (Stuart et al. 1999). Zheng et al. (2010) give examples of the importance of such relations in the field of biotechnology. The benefits of external networks include, for example, the transfer of know-how and technology, cooperation and mutual exchange. They examined the influence of these factors on a sample of 102 cases of start-up financing. On the basis of the data they collected from each of the projects, they estimated regression coefficients of explanatory variables (the start-up characteristics listed) with respect to the response variable (the valuation of the project at the time it received funding from venture capital and business angels). The estimation was performed by means of ordinary least squares (OLS) and, to eliminate heteroscedasticity, the technique of the generalized method of least squares (GLS) in several variants with the use of control variables (market size, profitability, the value of the stock market, etc.). The regression coefficients of the above characteristics of the start-ups proved statistically significant at least at the $5 \%$ significance level for the determination of the true valuation at the time at which they raised funds. According to empirical research, all three approaches to valuation - based on a) the industry structure, b) the internal sources of start-ups, and c) the external links of the start-ups - are relevant.

Existing approaches to valuation may well serve to valuate and compare projects within a single environment. If, however, the environments are different, it is logical that there are differences in risk perception on the part of investors and, therefore, in their decisions regarding the projects valuated. Although projects may exhibit identical characteristics (listed above), they may be valuated differently if they are to be implemented in different environments.

The attractiveness of the environment for business angels and venture capital investments is therefore different in individual countries, it influences the investors' willingness to invest, and is also reflected in the required 
rate of return on investment and, consequently, in project valuations. Various levels of attractiveness of the investee company's environment may explain different levels of venture capital activities in different countries. However, as noted by Zinecker and Bolf (2015), they are also influenced by other exogenous factors.

Some authors conclude that the environment is more attractive for investments if the economy is growing rapidly (Gompers and Lerner 1999) or that venture capital investments are related to the economic cycle (Romain, van Pottelsberghe 2003). Many studies emphasize the importance of well-developed capital markets (Gompers and Lerner 2000) and the interdependencies among them (Pietrzak et al. 2017). Jeng and Wells (2000) make a link between IPO activity and cyclic changes in venture capital. Black and Gilson (1998) emphasize the importance of a well-developed capital market with regard to exit investments. Similarly to Greene (1998), they note that a financial system dominated by banks is less favourable for start-up funding.

Other authors (e.g. Gompers and Lerner 2000) highlight the fact that venture capital and business angel activities are affected by the tax system. Cullen and Gordon (2002) note that taxation affects entry and exit behaviour as well as entrepreneurial activities (Djankov et al. 2008).

Another important parameter for venture capitalists and business angels influencing the level of their investments is the regulatory environment determining investment protection and corporate governance (La Porta et al. 1997, 1998). Differences between regulatory environments in different countries have also been noted by Djankov et al. (2002, 2008). Cumming et al. (2006) attach even more weight to the regulatory environment for venture capital and business angel investments than to a functional capital market. According to La Porta et al. (2002) and Lerner and Schoar (2005) weaker investment protection in a country translates into higher costs of capital.

A number of authors (e.g. Black and Gilson 1998, Lee and Peterson 2000) point out that the business environment is determined by the national culture. Djankov et al. (2002) investigated the effects of corruption, the crime rate, bureaucracy, etc. Black and Gilson (1998) note that labour market restrictions affect venture capital activity.

The suitability of the environment for venture capital investments may also change over time, as Månsson and Landström (2006) demonstrated with the example of Sweden. The authors concluded that there is a need to modify existing approaches to valuation by including the effects of the environment in which venture capitalists and angel investors make their investments. While this aspect is given some attention (e.g. Damodaran 2006), it is limited to a general description of the risks in a given country through, for example, credit default swaps (CDS), the country rating or the yield spreads of bonds as determined by the state of public finances, monetary and fiscal policies, etc.

Based on the above, it can be concluded that the existing methods of start-up valuation from the point of view of business angels and venture capitalists seek to compensate for the lack of information necessary for a standard company valuation with additional information on the entrepreneurial project, although they vary in their approach. None of the existing approaches, however, takes into consideration information about the environment in which the business angel and venture capitalists are to make their investments. The characteristics of the business environment are not reflected in existing start-up valuation models. Therefore, this paper aims to modify the existing theoretical models of start-up valuation by reflecting the factors of business environment.

\section{Methodology and research design}

The purpose of this study is to gain a greater understanding of the formal and informal venture capital investments valuation. The venture capital investments in startups are of a high level of risks and thus high required returns are typical of this investment category. The research approach was developed after an extensive review of venture capital-oriented academic literature (Snieska and Venckuviene 2011). Research methods cover the comparative analysis of scientific literature documents and reports as well as statistic data. The nature of this study is explorative. It relies on secondary data that was collected using interviews and semi-structured questionnaires in previous empirical studies.

The starting point for the definition and evaluation of exogenous variables mapping information about the environment in which the venture capital investments are made is the "Venture Capital \& Private Equity Country Attractiveness Index" (hereinafter the Index) published annually since 2009 (Groh et al. 2016). Based on normalized data from international institutions, the Index assesses the attractiveness of more than 100 countries in terms of PE\&VC investments based on evaluation of the following six areas: economic activity, capital markets, tax environment, investor protection and corporate governance, labour and social environment, and business opportunities. The Index is calculated for more than 100 countries around the world. During the course of the modelling process, information on the quality of the investee companies' environment expressed as the Index is incorporated into the established start-up project valuations.

We used the CAPM model as the basis for adjusting of existing valuation approaches. The commonly used formula for determining the cost of equity in international environment is as follows (Damodaran 2006):

$$
R_{e}=R_{f}+\beta_{d}\left[R_{m}-R_{f}\right]+R_{\text {country }},
$$

where $R_{e}$ is the cost of equity, $R_{f}$ is the risk-free interest rate, $\beta_{d}$ is the beta coefficient of an indebted company, $\left[R_{m}-R_{f}\right]$ is the market risk premium, and $R_{\text {country }}$ is the country risk premium (the country risk premium should 
be distinguished from the environment suitability for business angel investments). The field of operation, the company's operating leverage and the financial leverage used are considered determinants of the $\beta$ coefficient magnitude. The $\beta_{\mathrm{d}_{\mathrm{i}}}$ of an asset is calculated as the ratio between the covariance of that asset with the market portfolio and the market portfolio variance $\left(\beta_{\mathrm{d}_{\mathrm{i}}}=\operatorname{Cov}_{\mathrm{im}} /\right.$ $\left.\sigma_{\mathrm{m}}^{2}\right)$. For an estimate in the case of start-ups for which we struggle with a lack of historical data, we can use the following equation to estimate the impact of indebtedness:

$$
\beta_{d}=\beta_{d-\text { free }}[1+(1-t) D / E],
$$

where $\beta_{d-\text { free }}$ is the beta coefficient of a debt-free company, $t$ the marginal tax rate, $D$ the magnitude of debt, and $E$ the market value of equity. An estimate of the $\beta_{d \text {-free }}$ coefficient of a debt-free company can be made on the basis of an estimate of debt-free betas in the given industry. Based on equations (3) and (4) the cost of equity can be than expressed as the follows:

$R_{e}=R_{f}+\beta_{d-\text { free }}[1+(1-t) D \quad E]\left[R_{m}-R_{f}\right]+R_{\text {country }}$.

As our original proposal consists of a modification of the $\beta$ coefficient calculation for a given type of start-up projects, an essential part of the modification is also a proposal for the extension of the project scoring characteristics to include expert estimates and, in the case of regression analysis, the inclusion of explanatory variables expressing the suitability of the environment for venture capital investments.

The starting point for incorporating information on the investee company's environment is the model by Festel et al. (2013). The model is based on the CAPM (Eq. (1)). The authors recommend a modification of the calculation of the $\beta_{i}$ coefficient on the basis of information about the start-up projects. The modification consists in evaluation of start-up projects in five areas by experts and subsequent adjustment of the $\beta$ coefficient. The areas under evaluation and consequent changes in the coefficient are shown in Table 1.

$$
\beta=\hat{\beta}+\sum_{i=1}^{5} b_{i}
$$

The beta coefficient is adjusted according to the formula: where $\hat{\beta}$ is an estimation of the beta coefficient of a debtfree company in the respective industry and $\beta_{i}$ is the startup valuation score in the given area in the interval $\langle-4$; $4>$.

We also reflect the modification applied by Stankevičienè and Žinyte (2011), who propose evaluating business angel projects in Lithuania on the basis of 22 criteria in six areas (Table 2). The weightings of individual criteria are determined by an expert estimate. None of the criteria applied, however, reflects environment characteristics, although the authors state that they are also important for decision making.

The start-up project score is determined by the formula

$$
S_{j}=\sum_{i=1}^{m} \omega_{i} \tilde{r}_{i j}
$$

where $S_{j}$ is the sum of weighted normalized values of all the criteria calculated for the $j$-th project, $m$ is the number of the criteria used, $\omega_{i}$ is the weight of the i-th criterion, $\tilde{r}_{i j}$ is normalized $i$-th criterion's value for $j$-th object.

The next approach to evaluating start-up projects we used in our consideration is the model by Miloud et al. (2012). The authors assume that the value of start-ups can

Table 1. Assessment categories of start-up projects and adjustment of the $\beta$ coefficient (source: Festel et al. 2013).

\begin{tabular}{l|c|c|c}
\hline \multicolumn{1}{c|}{ Category } & Number of subcategories & $\begin{array}{c}\text { Maximal positive adjustment of } \\
\text { beta coefficient (in points) }\end{array}$ & $\begin{array}{c}\text { Maximal negative adjustment of } \\
\text { beta coefficient (in points) }\end{array}$ \\
\hline Technology & 4 & -4.00 & 4.00 \\
\hline Product & 4 & -4.00 & 4.00 \\
\hline Implementation & 4 & -4.00 & 4.00 \\
\hline Organization & 4 & -4.00 & 4.00 \\
\hline Finance & 4 & -4.00 & 4.00 \\
\hline
\end{tabular}

Table 2. Assessment categories of the start-up projects (source: Stankevičienė and Žinytė 2011).

\begin{tabular}{l|c|c}
\hline \multicolumn{1}{c|}{ Global criteria } & Number of sub-criteria & Global weights \\
\hline Owner's profile & 6 & 0.0394 \\
\hline External ties & 2 & 0.0692 \\
\hline Market opportunities & 2 & 0.0758 \\
\hline Investment period & 2 & 0.0217 \\
\hline Financing model & 2 & 0.0292 \\
\hline Portfolio company's profile & 8 & 0.0465 \\
\hline
\end{tabular}


be expressed as the linear combination of the project's characteristics:

$$
\hat{y}_{i}=\beta_{0}+\beta_{1} x_{i 1}+\beta_{2} x_{i 2}+\ldots+\beta_{k} x_{i k}+e_{i},
$$

where $y_{i}$ is the value of $i$-th start-up project, $x_{i 1}$ to $x_{i n}$ are the $i$-th start-up characteristics, $\beta_{0}$ to $\beta_{k}$ are the regression coefficients and $\varepsilon_{i}$ is the random error. The estimates $\beta_{0}$ to $\beta_{k}$ of the regression coefficients $\beta_{0}$ to $\beta_{k}$ can be obtained in a matrix based on the formula by Heij et al. (2004):

$$
\hat{b}=\left(X^{\prime} X\right)^{-1} X^{\prime} y
$$

Miloud et al. (2012) developed the model in terms of a sample of start-ups in just one country (France). Thus, it is impossible to demonstrate the effects of environment suitability on the valuation of investments.

The rest of the paper is organized as follows. The fourth part provides detailed and accurate research design and procedures. The fifth part contains empirical findings. Finally, there is a discussion and conclusion part that summarises and provides concluding remarks.

\section{Proposals for modification of existing valuation models - reflecting external determinants}

In this section we aim to make proposals for modification of existing valuation models by reflecting the influence of the external determinants and thus evaluating environment suitability for business angel and venture capital investments. Firstly, we modify the model by Festel et al. (2013). The modification consists in the adjustment of the magnitude of the $\beta$ coefficient that enters into the calculation of the cost of equity and thereby affects the valuation of the entire project. If we keep to the logic of this approach - adjustment of the $\beta$ coefficient for calculating the cost of equity according to the degree of project maturity in that area) - we could take advantage of the countries' ranking assessment expressed by the Index (Groh et al. 2016). Our expert proposal of the $\beta$ coefficient adjustment is shown in Table 3.

Table 3. Adjustment of $\beta$ coefficient - expert proposal (soure: own elaboration).

\begin{tabular}{l|c}
\hline $\begin{array}{c}\text { Country ranking } \\
\text { reflected by the Index }\end{array}$ & $\begin{array}{c}\text { Adjustment of the } \\
\boldsymbol{\beta} \text { coefficient }\end{array}$ \\
\hline $1^{\text {st }}$ quintile $\mathrm{Q}_{1 / 100}$ & -4.00 \\
\hline $2^{\text {nd }}$ quintile $\mathrm{Q}_{2 / 100}$ & -2.00 \\
\hline $3^{\text {rd }}$ quintile $\mathrm{Q}_{3 / 100}$ & no adjustment \\
\hline $4^{\text {th }}$ quintile $\mathrm{Q}_{4 / 100}$ & +2.00 \\
\hline $5^{\text {th }}$ quintile $\mathrm{Q}_{5 / 100}$ & +4.00 \\
\hline
\end{tabular}

Assessment categories of start-up projects and adjustments of the $\beta$ coefficient in the interval $<-4 ; 4>$ are shown in Table 1. We propose assessing the environment suitability for venture capital investments on the same principal. The modification of the $\beta$ coefficient is based on the value of the Index (Groh et al. 2016). The distribution of countries is expressed in Table 3. If the environment for venture capital investments in a given country is exceptionally favourable, the $\beta$ coefficient will be reduced. Should the external environment be unfavourable, the $\beta$ coefficient - and thereby the cost of equity - will increase proportionally. The approach that uses the $\beta$ coefficient to incorporate project maturity and project prerequisites for successful implementation into the cost of equity has thereby been enhanced by taking the business environment into account. It is obvious that this approach can contribute to a more accurate estimation of the cost of equity and may also help explain the different levels of investments made by business angels and venture capitalists in different countries.

Calculation of the $\beta$ coefficient reflecting the assessment of the environment's suitability for venture capital investments is based on the formula as follows:

$$
\beta=\hat{\beta}+\sum_{i=1}^{5} b_{i}+b_{E}
$$

where $b_{E}$ is the score of the assessment of the environment's suitability for venture capital investments. After all the evaluated project criteria have been taken into account, we obtain the following formula for the calculation of the cost of equity:

$$
R_{e}=R_{f}+\left[\hat{\beta}_{d-f r e e}+\sum_{i=1}^{5} b_{i}+b_{E}\right][1+(1-t) D / E]\left[R_{m}-R_{f}\right]+R_{\text {country }} .
$$

It follows from the formula (11) that inclusion of $b_{E}$ may significantly affect the project's cost of equity, particularly if it relies on debt financing or in the case of high-risk premiums, and it may consequently affect the decision as to whether the investment will be conducted in the given environment (country).

\section{Case study}

In order to verify the model, we use the case study as research approach. For this purpose three countries differing significantly in the quality of economic and political environment were selected. The first economy represents the United Kingdom (a well-developed market economy), the second Lithuania (an emerging market fully integrated into European economic and political treaty structures) and the third Belarus (an emerging market standing outside the European integration). Table 3 shows the current valuation of the parameter assessing the suitability of the business environments in the individual country and the formula (11) expresses calculation of the required rate of return with respect to the environment. The impact of the proposed model modification on the cost of equity is shown in Table 4 . 
Essential differences in the required rate of return are obvious. The parameter $K$ in the Table 4 stands for the market premium and the influence of the project's capital structure.

\section{Further modifications}

Another modification concerns the approach of Stankevičienè and Žinytė (2011). As mentioned in the theoretical part, this model does not reflect characteristics of the environment. The outcome of this valuation model is a score. The weightings of individual criteria included into the model are determined by an expert estimate. We propose to modify this model again by including criteria of environment suitability from the perspective of start-up projects. Given that the criteria are rated on a five point scale $(1$ - weakest rating, 5 - best rating), the assessment of environment suitability for venture capital can use the same distribution of quintiles when evaluating individual countries. Individual criteria weightings are determined by expert estimates.

The model by Stankevičienè and Žinytè (2011) formulated by the formula (7) is modified as follows:

$$
S_{n e w \mathrm{j}}=\sum_{i=1}^{n} w_{i} r_{i j}+w_{n+1} r_{\text {environment } \mathrm{j}}
$$

where

$$
\sum_{i=1}^{n+1} w_{i}=1
$$

where $w_{i}$ are the new weightings of the given criterion, rij is the value of criteria included in the original model, and $w_{\mathrm{n}+1} r_{\text {environment } \mathrm{j}}$ expresses the weightings and the value of criteria evaluating the business environment. $S_{\text {new } j}$ is the value of the project while applying the modified model.

The impact of individual factors on the start-up project value according to the formulas (8) and (9) can be calculated from empirical data (Miloud et al. 2012). While using regression analysis, the modified model is as follows:

$$
\begin{aligned}
& y_{\text {newi }}=\beta_{0}+\beta_{1} x_{\mathrm{i} 1}+\beta_{2} x_{\mathrm{i} 2}+\ldots+ \\
& +\beta_{n} x_{\text {in }}+\beta_{\text {Enviroment }} \mathrm{x}_{\text {iEnviroment }}+e_{i},
\end{aligned},
$$

where $\beta_{1}$ to $\beta_{n}$ and $x_{i 1}$ to $x_{i n}$ are regression coefficients and explanation variables as expressed in the original model and $\beta_{\text {Environment }} x_{\text {iEnvironment }}$ is the regression coefficient and an explanatory variable representing the suitability of the environment for start-ups. Therefore, $y_{\text {new }_{i}}$ is the new estimated value of the start-up project and $e_{i}$ is an estimate error.

A summary of the above proposals for the modification of the existing models is in Table 5. The third column of the table contains proposals for possible modifications of selected approaches consisting in the inclusion of the effects of environment suitability for the respective investment and thereby increasing the accuracy of project valuation. Table 6 also summarizes the proposed modifications of models in question as well as the data sources.

Table 4. Impact of the suitability of business environment on the required rate of return of projects in selected countries (source: own elaboration).

\begin{tabular}{l|c|c|c}
\hline \multicolumn{1}{c|}{ Country } & United Kingdom & Lithuania & Belarus \\
\hline Ranking of the country (expressed by the Index) & $1^{\text {st }}$ quintile & $2^{\text {nd }}$ quintile & $4^{\text {th }}$ quintile \\
\hline Value assigned to the c parameter & -4.00 & -2.00 & 2.00 \\
\hline Increase in the required rate of return on investment in comparison to the UK & & $2.00 \times \mathrm{K}$ & $6.00 \times \mathrm{K}$ \\
\hline \multicolumn{2}{c|}{ Where $K=[1+(1-t) D / E]\left[R_{m}-R_{f}\right](12)$} & \\
\hline
\end{tabular}

\begin{tabular}{|c|c|c|c|c|}
\hline Model & Original calculation & Modified calculation & Data sources & Expected sign \\
\hline $\begin{array}{l}\text { Festel et al. } \\
(2013)\end{array}$ & $\beta=\hat{\beta}+\sum_{i=1}^{5} b_{i}$ & $\beta=\hat{\beta}+\sum_{i=1}^{5} b_{i}+b_{E}$ & $\begin{array}{l}\text { Venture Capital \& Private Equity } \\
\text { Country Attractiveness Index }\end{array}$ & $+/-$ \\
\hline $\begin{array}{l}\text { Stankevičienė } \\
\text { and Žxnytė } \\
(2011)\end{array}$ & $S_{j}=\sum_{i=1}^{m} \omega_{i} \tilde{r}_{i j}$ & $\begin{array}{l}S_{\text {new } \mathrm{j}}= \\
=\sum_{i=1}^{n} w_{i} r_{i j}+w_{n+1} r_{\text {environment } \mathrm{j}}\end{array}$ & $\begin{array}{l}\text { Venture Capital \& Private Equity } \\
\text { Country Attractiveness Index }\end{array}$ & $+/-$ \\
\hline $\begin{array}{l}\text { Miloud et al. } \\
(2012)\end{array}$ & $\begin{array}{l}\hat{y}_{i}= \\
=\beta_{0}+\beta_{1} x_{i 1}+\beta_{2} x_{i 2}+\ldots \\
+\beta_{k} x_{i k}+e_{i}\end{array}$ & $\begin{array}{l}\hat{y}_{\text {new }}= \\
=\beta_{0}+\beta_{1} x_{\mathrm{i} 1}+\beta_{2} x_{\mathrm{i} 2}+\ldots \\
+\beta_{n} x_{\text {in }}+\beta_{\text {Enviroment }} \mathrm{x}_{\text {iEnviroment }}+e_{i}\end{array}$ & $\begin{array}{l}\text { Venture Capital \& Private Equity } \\
\text { Country Attractiveness Index }\end{array}$ & $+/-$ \\
\hline
\end{tabular}

Table 5. Approaches of start-ups valuation and their modifications (source: own elaboration).

\begin{tabular}{l|l|l}
\hline \multicolumn{1}{c|}{ Approach/Authors } & \multicolumn{1}{c}{ Benefits/limitations } & \multicolumn{1}{c}{ Proposed modification } \\
\hline $\begin{array}{l}\text { Modification of the } \beta \\
\text { coefficient }\end{array}$ & $\begin{array}{l}\text { Captures the influence of project characteristics on the } \\
\text { Festel et al. (2013) }\end{array}$ & $\begin{array}{l}\text { Further modifications of the } \beta \text { coefficient by indicators of } \\
\text { environment suitability and venture capital investments }\end{array}$ \\
\hline $\begin{array}{l}\text { Stankevičiené and Žxnytè } \\
(2011)\end{array}$ & $\begin{array}{l}\text { Captures specific conditions of start-up projects/Only } \\
\text { scores are expressed, cash flows are not specified }\end{array}$ & $\begin{array}{l}\text { Additional areas assessing the suitability of the business } \\
\text { environment for venture capital investments }\end{array}$ \\
\hline $\begin{array}{l}\text { Regression analysis } \\
\text { Miloud et al. (2012) }\end{array}$ & $\begin{array}{l}\text { Regression coefficients' estimation reflecting environ- } \\
\text { ment suitability/For a single country only }\end{array}$ & $\begin{array}{l}\text { Regressors estimation expressing the quality of the envi- } \\
\text { ronment for venture capital investments }\end{array}$ \\
\hline
\end{tabular}

Table 6. Approaches of start-ups valuation and the modifications of calculations (source: own elaboration). 


\section{Discussion}

There are many limitations while valuing start-ups. The most challenging is the insufficient amount of data for valuation as expressed by recent cash flows (Kumar 2015). Michalak (2016) points out the relation between the cost of capital and the company value and concludes that the cost of capital is one of the main parameters of company assessment. The existing approaches seek to address this specific aspect of start-up valuation. The determination of an overall valuation or, rather, determination of the impact of various factors on the overall valuation in the form of models has been attempted by many empirical studies, e.g. Festel et al. (2013) (modification of the $\beta$ coefficient for determining the cost of equity), Stankevičienè and Žinyte (2011) (scoring individual criteria for determining the total score - attractiveness) and Miloud et al. (2012) (estimates of regression coefficients of selected criteria). Based on a systematic literature review The weakness of these approaches is that they do not take into account research studies on the influence of the business environment that should be also reflected while valuating start-ups. The valuation approaches of Festel et al. (2013), Stankevičienė and Žinytė (2011) and Miloud et al. (2012) do not reflect the differences between countries concerning their attractiveness for venture capital investments. Valuation results based on these approaches may then tend to overvalue investments in countries with a less favourable business environment, and disregard the attractiveness of those with a more favourable environment. This drawback could be overcome with the findings by Groh et al. (2010), who compiled a list of countries ranked according to their attractiveness for venture capital and business angel investments. The authors take into considerations the influence of the environment and calculate an index expressing the attractiveness of individual countries from the venture capitalists' perspective.

Therefore, we aim to develop an approach considering factors of the investee companies' environment within our investigation. The starting point for our modifications are approaches that modify the $\beta$ coefficient in the calculation of the cost of equity (Festel et al. 2013), the score of individual start-up project characteristics (Stankevičienè and Žinyte 2011), and that use regression to estimate the importance of start-up project characteristics (Miloud et al. 2012). The key modifications of the models consist in the inclusion of the factor of business suitability when valuing a start-up project. This results in a further modification of the $\beta$ coefficient for calculating the cost of equity, more accurate scoring of projects in an international comparison, and a more accurate estimate of the significance of each parameter in the linear regression model. In comparison to previous models our approach uses the adjusted value of the $\beta$ coefficient, which takes differences in business environment in individual countries into account. This results in a greater accuracy in the required rate on return calculations in different environments from the perspective of venture capital investments. Differen- tiation of the approach to the $\beta$ coefficient calculations by country may also help to explain the different levels of investments made by business angels and venture capitalists in individual countries. This can be seen as another contribution of our investigation within academic discussion on the issue.

\section{Conclusions}

The aim of this article is to contribute to a better understanding of the valuing start-ups from the venture capitalists' perspective. The nature of this study is explorative. It relies on secondary data that was collected using interviews and semi-structured questionnaires in previous empirical studies. During the course of the modelling process, information on the quality of the investee companies' environment expressed is incorporated into the established start-up project valuations.

Our original proposal consists of the modification of the $\beta$ coefficient calculation for a given type of projects. An essential part of this modification is also a proposal for the extension of the project scoring characteristics to include expert estimates and, in the case of regression analysis, the inclusion of explanatory variables expressing the suitability of the environment for venture capital investments. This modification of existing valuation approaches will allow a more accurate valuing of the projects and thus is contributing for enterprises seeking for capital, formal and informal venture capitalists, investment bankers and macroeconomic policy makers.

To empirically verify the effects of the factor of environment suitability for business angel or venture capital investments, it would be desirable to extend the proposed model adjustments by evaluating venture capital projects implemented in different countries (i.e. different business environments). Statistical significance, direction, the magnitude of regression coefficients of regressors of the environment would help to better assess their importance in the context of other variables affecting the final start-up valuations. Therefore, future investigations should focus on, for example, the extent to which factors of environment suitability for start-up investments in individual countries are translated into differences in the required rate of return on capital invested in start-ups, and to what extent they can explain the different levels of venture capital investments in each of these countries. With minimum adjustment, the result of this index can be included in the calculation of $\beta$ coefficient modifications or included in the scores of attractiveness for venture capital or business angel investments.

\section{Disclosure statement}

Authors declare that they have no competing financial, professional, or personal interests from other parties. 


\section{References}

Black B, Gilson R (1998) Venture capital and the structure of capital markets: banks versus stock markets. Journal of Finance Economics 47(3): 243-277. https://doi.org/10.1016/S0304-405X(97)00045-7

Brealey R, Myers S, Allen F (2007) Principles of Corporate Finance ( $9^{\text {th }}$ edn). McGraw Hill Higner Education, New York, 976 pp.

Capizzi V (2015) The returns of business angels' investments and their major determinants. Venture Capital: An International Journal of Entrepreneurial Finance 17(4): 271-298. https://doi.org/10.1080/1 3691066.2015.1092264

Carpentier C, Suret JM (2015) Angel group members' decision process and rejection criteria: a longitudinal analysis. Journal of Business Venturing 30(6): 808-821. https://doi.org/10.1016/j. jbusvent.2015.04.002

Cullen JB, Gordon RH (2002) Taxis and Entrepreneurial Activity: Theory and Evidence for the U.S. Working Paper 9015. Cambridge (MA), NBER.

Cumming D, Fleming G, Schwienbacher A (2006) Legality and venture capital exits. Journal of Corporate Finance 12: 214-245. https://doi. org/10.1016/j.jcorpfin.2004.12.004

Damodaran A (2006) Damodaran on Valuation: Security Analysis for Investment and Corporate Finance ( $2^{\text {nd }}$ edn). Wiley, Hoboken, 42-45.

Djankov S, La Porta R, Lopez-de-Silanes F, Shleifer A (2002) The regulation of entry. Quarterly Journal of Economics 117(1): 1-37. https://doi.org/10.1162/003355302753399436

Djankov S, Ganser T, McLiesh C, Ramalho R, Shleifer A (2008) The effect of corporate taxes on investment and entrepreneurship. NBER Working Paper 13756. https://doi.org/10.3386/w13756

Festel GW, Wuermseher M, Cattaneo G (2013) Valuation of early stage high-tech startup companies. International Journal of Business 18(3): 216-231.

Franke N, Gruber M, Harhoff D, Henkel J (2008) Venture capitalists evaluations of startup teams: trade-offs, knock-out criteria, and the impact of VC experience. Entrepreneurship Theory and Practice 32: 459-483. https://doi.org/10.1111/j.1540-6520.2008.00236.x

Ge D, Mahoney JM, Mahoney JT (2005) New venture valuation by venture capitalists: an integrative approach. Working Paper. University of Illinois at Urban Champaign 124: 5-124.

Gimeno J, Folta T, Cooper A (1997) Survival of the fittest? Entrepreneurial human capital and the persistence of underperforming firms. Administrative Science Quarterly 42: 750-783. http://dx.doi.org/ $10.2307 / 2393656$

Gompers P, Lerner J (1999) What drives venture capital fundraising?, Working Paper 6906. Natural bureau of economic research. https:// doi.org/10.3386/w6906

Gompers P, Lerner J (2000) Money chasing deals? The impact of fund inflows on private equity valuations. Journal of Financial Economics 55: 281-325. https://oi.org/10.1016/S0304-405X(99)00052-5

Greene PG (1998) Dimensions of perceived entrepreneurial obstacles. $18^{\text {th }}$ Frontiers of Entrepreneurship Research, 1998, Ghent, Belgium.

Groh A, von Liechtenstein H, Lieser L, Biesinger M (2016) The Venture Capital \& Private Equity Country Attractiveness Index. http://blog. iese.edu/vcpeindex [29 February 2016]

Groh AP, von Lichtenstein H, Lieser K (2010) The European venture capital and private equity country attractiveness indices. Journal of Corporate Finance 16: 205-224. https://doi.org/10.1016/j.jcorpfin.2009.09.003
Heij C, de Boer P, Franses PH, Kloek T, van Dijk HK (2004) Economectic Methods with Applications in Business and Economics. Oxford University Press, Oxford, 122 pp.

Jeng LA, Wells PhC (2000) The determinants of venture capital funding: evidence across countries. Journal of Corporate Finance 6(3): 241-289. https://doi.org/10.1016/S0929-1199(00)00003-1

Kumar R (2015) Valuation: Theories and Concepts. Academic Press, Sqan Diengo, 23 pp.

La Porta R, Lopez-de-Silanes F, Shleifer A, Vishny R (1997) Legal determinants of external finance. Journal of Finance 52(3): 1131-1150. https://doi.org/10.2307/2329518

La Porta R, Lopez-de-Silanes F, Shleifer A, Vishny R (1998) Law and finance. Journal of Political Economy 106(6): 1113-1155. https:// doi.org/10.1086/250042

La Porta R, Lopez-de-Silanes F, Shleifer A, Vishny R (2002) Investor protection and corporate valuation. Journal of Finance 57(3): 11471170. http://www.jstor.org/stable/2697775

Larson A, Starr J (1993) A network model of organization formation. Entrepreneurship: Theory \& Practice 17: 5-15.

Lee SM, Peterson SJ (2000) Culture, entrepreneurial orientation and global competiveness. Journal of World Business 35(4): 401-416. https://doi.org/10.1016/S1090-9516(00)00045-6

Lerner J, Schoar A (2005) Does legal enforcement affect financial transactions? The contractual channel in private equity. Quarterly Journal of Economics 120(1): 223-246. http://www.jstor.org/stable/25098735

Månsson N, Landström H (2006) Business angels in a changing economy: the case of Sweden. Venture Capital: An International Journal of Entrepreneurial Finance 8(4): 281-301. https://doi. org/10.1080/13691060600836275

Mason CM, Stark M (2004) What do investors look for in a business plan? International Small Business Journal 22: 227-248. https://doi. org/10.1177/0266242604042377

Maxwell AL, Jeffrey SA, Lévesque M (2011) Business angels early stage decision making. Journal of Business Venturing 26: 212-225. https://doi.org/10.1016/j.jbusvent.2009.09.002

Michalak A (2016) The cost of capital in the effectiveness assessment of financial management in a company. Oeconomia Copernicana 7(2): 317-329. http://dx. doi.org/10.12775/OeC.2016.019

Miloud T, Apelund A, Cabrol M (2012) Startup valuation by venture capitalists: an empirical study. Venture Capital: An International Journal of Entrepreneurial Finance 14: 151-174. https://doi.org/10 $.1080 / 13691066.2012 .667907$

Mitteness CR, Baucusb MS, Sudek R (2012) Horse vs. Jockey? How stage of funding process and industry experience affect the evaluations of angel investors. Venture Capital: An International Journal of Entrepreneurial Finance 14(4): 241-267. https://doi.org/10.1080/13 691066.2012.689474

Nofsinger JR, Wang W (2011) Determinants of start-up firm external financing worldwide. Journal of Banking and Finance 35(9): 22822294. https://doi.org/10.1016/j.jbankfin.2011.01.024

Peemöller VH, Geiger T, Barchet H (2001) Bewertung von Early-Stage Investment im Rahmen der Venture Capital Finanzierung. Finanz Betrieb 5: 334-344.

Pietrzak MB, Fałdziński M, Balcerzak AP, Meluzín T, Zinecker M (2017) Short-term shocks and long-term relationships of interdependencies among central European capital markets. Economics \& Sociology 10(1). http:dx.doi.org/10.14254/2071-789X.2016/10-1/5 
Porter M (1980) Competitive Strategy: Techniques for Analysing Industries and Competitors. Free Press, New York, 397 pp.

Romain A, van Pottelsberghe B (2003) The determinants of venture capital: a panel analysis of 16 OECD countries. Working Paper WPCEB 04/015. Institute of Innovation Research, Hitotsubashi.

Sanders WG, Boivie S (2004) Sorting things out: valuation of new firms in uncertain markets. Strategic Management Journal 25: 167-186. https://doi.org/10.1002/smj.370

Siegel R, Siege E, MacMillan I (1993) Characteristics distinguishing high grows ventures. Journal of Business Venturing 8: 169-180. https://doi.org/10.1016/0883-9026(93)90018-Z

Silva J (2004) Venture capitalists' decision making in small equity markets: a case study using participant observation. Venture Capital: An International Journal of Entrepreneurial Finance 6: 125-145. https:// doi.org/10.1080/13691060410001675974

Snieska V, Venckuviene V (2011) Hybrid venture capital funds in Lithuania: motives, factors and present state of development. Inzinerine Ekonomika-Engineering Economics 22(2): 157-164. https://doi. org/10.5755/j01.ee.22.2.312

Stankevičienė J, Žinytė S (2011) Valuation model of new startup companies: Lithuanian case. Business: Theory and Practice 12: 379-389. https://doi.org/10.3846/btp.2011.39
Stuart TE, Hoang H, Hybels, RC (1999) Interorganizational endorsements and the performance of entrepreneurial ventures. Administrative Science Quarterly 44: 315-349. https://doi.org/10.2307/2666998

Sudek R (2006) Angel investment criteria. Journal of Small Business Strategy 17: 89-103.

Timmons J (1992) New Venture Creation: Entrepreneurship in the 1990s ( $3^{\text {rd }}$ edn). McGraw-Hill//Irwin, New York, 677 pp.

Van Osnabrugge M, Robinson RJ (2000) Angel Investing: Matching Startup Funds with Startup Companies - The Guide for Entrepreneurs, Individual Investors, and Venture Capitalist. Jossey-Bass, San Francisco, $448 \mathrm{pp}$.

Zinecker M, Bolf D (2015) Venture capitalists investment selection criteria in CEE countries and Russia. Business: Theory and Practice 16(1): 94-103. https://doi.org/10.3846/btp.2015.441

Zheng Y, Liu J, George G (2010) The dynamic impact of innovative capability and inter-firm network on firm valuation: a longitudinal study of biotechnology start-ups. Journal of Business Venturing 25: 593-609. https://doi.org/10.1016/j.jbusvent.2009.02.001 